\title{
Project-Based Learning Using Discussion and Lesson-Learned Methods via Social Media Model for Enhancing Problem Solving Skills
}

\begin{abstract}
Chaiwat Jewpanich $^{1} \&$ Pallop Piriyasurawong ${ }^{1}$
${ }^{1}$ Division of Information and Communication Technology for Education, Faculty of Technical Education, King Mongkut's University of Technology North Bangkok, Bangkok, Thailand

Correspondence: Chaiwat Jewpanich, Division of Information and Communication Technology for Education, Information and Communication Technology for Education, Faculty of Technical Education, King Mongkut's University of Technology North Bangkok, Bangkok, Thailand. E-mail: jewpanich@hotmail.com

Co-correspondence: Pallop Piriyasurawong, Division of Information and Communication Technology for Education, Faculty of Technical Education, King Mongkut's University of Technology North Bangkok, Bangkok, Thailand. E-mail: palloppi@gmail.com
\end{abstract}

Received: December 31, 2014 Accepted: February 5, 2015 Online Published: May 27, 2015

doi:10.5539/ies.v8n6p24 URL: http://dx.doi.org/10.5539/ies.v8n6p24

\begin{abstract}
This research aims to 1) develop the project-based learning using discussion and lesson-learned methods via social media model (PBL-DLL SoMe Model) used for enhancing problem solving skills of undergraduate in education student, and 2) evaluate the PBL-DLL SoMe Model used for enhancing problem solving skills of undergraduate in education student. The samples groups are 9 specialists in education, enhancement of problem solving skills, educational technology, and computer and communication technology selected by purposive sampling. Thereafter, researcher analyses the data statistically by examining the mean $(\bar{x})$ and the standard deviation (S.D.).

The research result shows that (1) the PBL-DLL SoMe Model used for enhancing problem solving skills of undergraduate in education student, consists of 4 components which are 1) the analysis of the readiness of the input factors, 2) the process of the PBL-DLL SoMe Model, 3) the evaluation of the achievement of learning and problem solving skills (Output), and 4) the evaluation of the result between evaluating and feedback. (2) The evaluation result of this research project on the PBL-DLL SoMe Model for enhancing problem solving skills of undergraduate in education student shows that 1$)$ the mean $(\bar{x})$ of the results of evaluated input factor readiness is valued at 4.50. The The standard deviation (S.D.) is equal to 0.80.2) The mean ( $\bar{x})$ of the process PBL-DLL SoMe Model is valued at 4.52. The standard deviation (S.D.) is equal to 0.62.3) The mean $(\bar{x})$ of the evaluation of the achievement of learning and problem solving skill (Output) is valued at 4.62. The standard deviation (S.D.) is equal to 0.72 . 4) The mean $(\bar{x})$ of the evaluation between process and feedback is valued at 4.71 . The standard deviation (S.D.) is equal to 0.48. 5) The mean $(\bar{x})$ of the overall evaluation of the developed learning model is valued at 4.53 . The standard deviation (S.D.) is equal to 0.75 . Therefore, the developed learning model is rated as most appropriate in terms of quality.
\end{abstract}

Keywords: project-based learning, discussion, lesson-learned, social media, problem solving skill, undergraduate in education student

\section{Introduction}

National Education Act 1999 and amendments 2002, Article 9 (Office of the Basic Education Commission of Thailand, 2002) supports the creation of innovation and the application of technology in education for the maximum benefit.

At present, social media is very popular and has an interactive use that users can access to any social media comfortably and rapidly. Users can come to share their knowledge, information, and news to each other freely, and can comment each other immediately. This will not make you miss any piece of communication from the progress of social media online which is very beneficial for education (Pisek, 2012). 
In the context of education, there should be a designed model of project-based learning which is an instruction management emphasizing students by encouraging experience-building, self-learning for developing or strengthening any skills or toughening the process of learning (Bell, 2010). Under this based-learning project, student will find any information and knowledge to make a successful collaborative project. The process of collaborative project is to help each other to solve occurred problem within group by practical way to learn how to solve a problem for enhancing problem solving skills (Trakulsalid, n.d.). Learning by using learning discussion method is a technique that supports students participating in classroom by looking at how they express through commendation that reflects students' thought (Kamemanee, 2004). Moreover, learning by using lesson-learned method is to review and summarize work experiences in the past in every aspect in order to see the details of both internal and external factors that lead to either success or failure at present (Panmuk, 2009).

Therefore, this research will enhance and evaluate the PBL-DLL SoMe Model for enhancing problem solving skills of undergraduate in education student for the development of instruction for undergraduate in education.

\section{Objectives}

1) To develop the PBL-DLL SoMe Model for enhancing problem solving skills of undergraduate in education student.

2) To evaluate the PBL-DLL SoMe Model for enhancing problem solving skills of undergraduate in education student.

\section{Method}

\subsection{Scope of the Research}

This research aims to develop the PBL-DLL SoMe Model for enhancing problem solving skills of undergraduate in education student by having the scope of the research as follows:

The samples in this research are 9 specialists in education, enhancement of problem solving skills, educational technology, and computer and communication technology selected by purposive sampling since they are specialists related to the context of this research.

\subsection{Variables in the Research}

Independent variable is the PBL-DLL SoMe Model for enhancing problem solving skills of undergraduate in education student.

Dependent variable is the result of the evaluation of the PBL-DLL SoMe Model for enhancing problem solving skills of undergraduate in education student.

\subsection{Research Methodology}

The research is divided into 2 stages which are:

Stage 1. The development of the PBL-DLL SoMe Model for enhancing problem solving skills of undergraduate in education student consists of steps as follows:

1) Study and analyze research document.

2) Develop the research model in which the researcher has taken the concept of ADDIE Model to develop the PBL-DLL SoMe Model for enhancing problem solving skills of undergraduate in education student.

Stage 2. The evaluation of the PBL-DLL SoMe Model for enhancing problem solving skills of undergraduate in education student consists of steps as follows:

1) The developed learning model is evaluated by 9 specialists.

2) Analyze the result of evaluation by using appropriateness criteria (Kannasud, 1999).

\section{Result}

\subsection{Developed Model}

The model of PBL-DLL SoMe Model for enhancing problem solving skills of undergraduate in education student is shown in Figure 1. 
The project-based learning using discussion and lesson-learned methods via social media model for enhancing problem solving skills of undergraduate in education Student

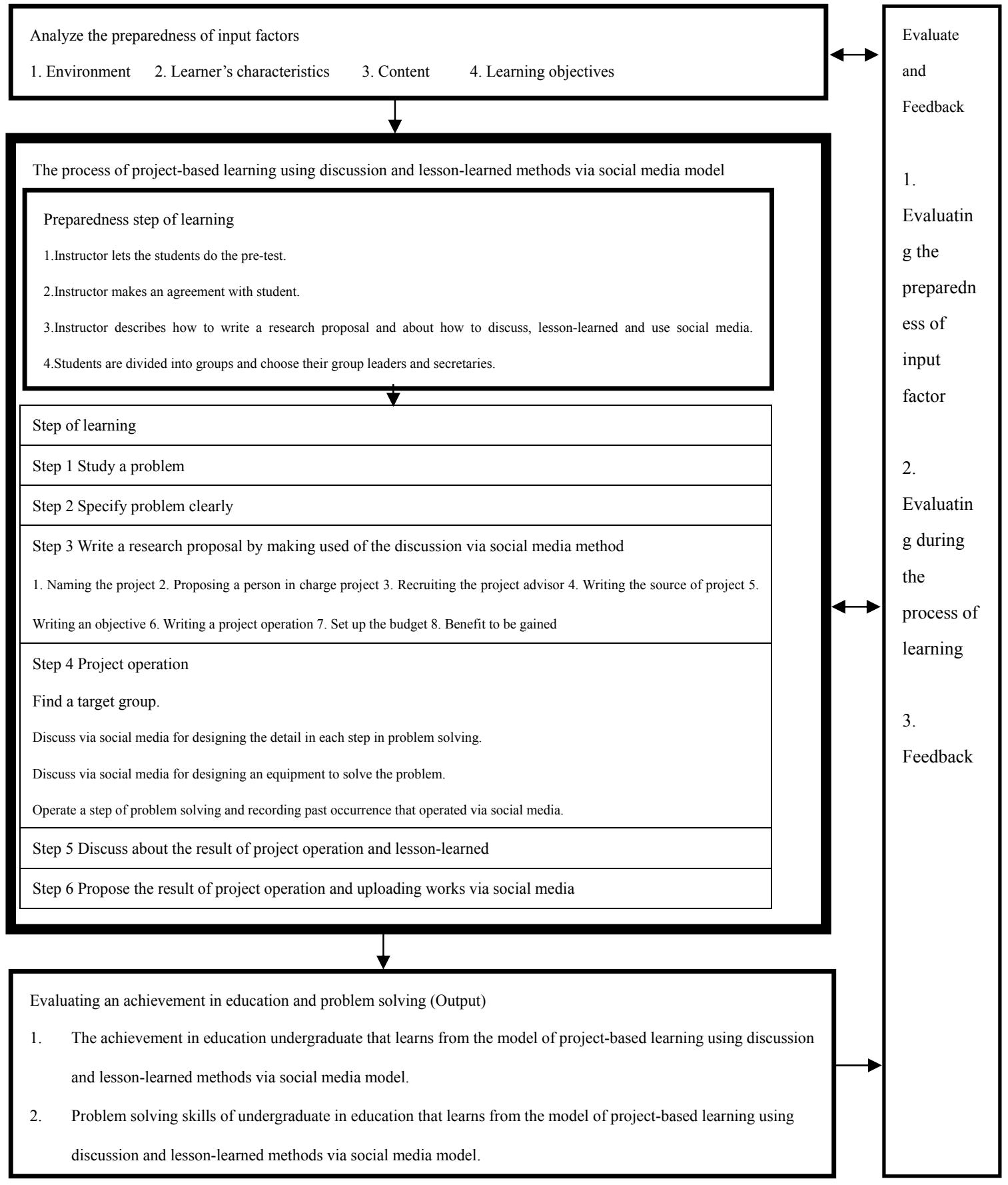

Figure 1. Project-based learning using discussion and lesson-learned methods via social media model for enhancing problem solving skills of undergraduate in education student (PBL-DLL SoMe Model)

The PBL-DLL SoMe Model for enhancing problem solving skills of undergraduate in education student is a developed model that consists of 4 components as below:

Analyzing readiness of input factor is a step that instructor will prepare before attend to a process of learning that 
has 4 sub-component. 1) Analyzing environment is a responsibility of instructor to provide classroom that has group seat. Each of group has computer that can connect to internet for using social media. 2) Analyzing students' characteristics is a responsibility of instructor that should analyze characteristics of students based on the standard. This means students should be undergraduates in education that have basic knowledge in using information and communication technology and in using computer measured by the criteria on basic knowledge in using information and communication technology and basic using computer of Information Technology Centre, Suan Sunandha Rajabhat University. 3) Analyzing content. Instructor has analyzed content for discussion in step of learning readiness. 4) Learning objective. Instructor is a learning objective designer by separating the objectives into 2 fields which are learning achievement and problem solving skills.

The process of PBL-DLL SoMe Model in this step is divided into 2 parts. The first part is the step of learning preparation. Instructor should create learning activities as follows: 1) Instructor let students do the pre-test. 2) Instructor makes a basic agreement with students as a basic rule before instructing. Moreover, that rule should be accepted by both students and instructors. 3) Instructor describes how to write a research proposal and about how to discuss, lesson-learned, and use social media which are topics of discussion derived from content analysis that students should know the steps and operation of learning activities. 4) Students are divided into groups and choose their group leaders and secretaries to prepare learners to join an activity in the stage of learning afterwards. For the second part, the process of learning consists of 6 stages as follows.

Stage 1. Studying problem has activities as follows: 1) instructor specifies problem situation in education. 2) Students make a study visit for researching about the problem. 3) Instructor evaluates learners based on their actual conditions.

Stage 2. Specifying problem clearly has activities as follows: 1) Students discuss together for better understanding about the problem and specifying topics clearly. 2) Instructor evaluates learners based on their actual conditions.

Stage 3. Writing a research proposal by making use of discussion via social media method has activities as follows: 1) Students discuss together for planning about writing the research project by looking at the topics as follows: name of the project, name of the person who is in charge of the project, name of the advisor of the project, the source of project, objectives, hypothesis, operation of project, budget and benefits to be gained based on the model. 2) Instructor evaluates

Stage 4. Project Implementation by having activities as follows: 1) Find a target group. 2) Discuss via social media for designing the details in each step for problem solving. 3) Discuss via social media for designing an equipment to solve the problem. 4) Operate problem solving process and record past occurrence that was operated via social media.

Stage 5. Discussion of the result of project operation and lesson-learned has activities as follows: 1) When complete the problem solving process after the 6 weeks, instructor provides place, computer, amplifier microphone for each activity to let learners discuss about the result of project operation. 2) Instructor uses activities to let learners practice lesson-learned by using review-after-practicing technique and knowledge derived from lesson-learned via social media online. 3) Instructor evaluates learners.

Stage 6. Proposing the result of project operation and uploading works via social media has activities as follows: 1) Student proposes their works from the project for propagating and uploading proposed files, research files, knowledge files by lesson-learned method via social media. 2) Instructor evaluates learners.

Evaluate the achievement in education and problem solving skills (Output). 1) The achievement in education of undergraduate in education that is studied in the research project on the PBL-DLL SoMe Model is come from the evaluation of pre-test and post-test. 2) Problem solving skills of undergraduate in education that is studied in the research project on the PBL-DLL SoMe Model is come from the evaluation of the process of PBL-DLL SoMe Model assessed under the actual conditions.

Evaluate the relationship between process and feedback by 1) evaluating the readiness of the input factors, 2) evaluate during the process of learning, and 3) feedback.

\subsection{The Result of the Evaluation of the Developed Learning Model Is Based on Table 1-5 as Below}

The researcher proposes the developed model to the specialists for evaluation. The result is concluded as follows: 
Table 1. Analysis of the readiness of the input factors

\begin{tabular}{lllll}
\hline Details & $\bar{x}$ & S.D & The quality level \\
\hline 1. Environment & 4.44 & 0.53 & Very appropriate \\
2. Learners' characteristics & 4.56 & 0.53 & Most appropriate \\
3. Content & 4.11 & 1.27 & Very appropriate
\end{tabular}

4. Learning objectives

4.1 The achievement in education

4.1.1 Student can describe the operation of the project

4.1.2 Student can describe the process of discussion

4.1.3 Student can describe the process of lesson-learned

4.1.4 Student can describe the method of using social media online

4.1.5 Student can write a research proposal

4.2 Problem solving skills

4.2.1 Student can analyze the cause of problem

4.2.2 Student can classify the components of problem

4.2.3 Student can implement a project for solving a problem

4.2.4 Student can design a method for solving a problem

4.2.5 Student can operate project for solving a problem $\begin{array}{lll}4.44 & 0.73 & \text { Very appropriate } \\ 4.44 & 0.88 & \text { Very appropriate } \\ 4.44 & 0.88 & \text { Very appropriate } \\ 4.46 & 0.88 & \text { Very appropriate } \\ 4.67 & 0.71 & \text { Most appropriate }\end{array}$

$4.78 \quad 0.44 \quad$ Most appropriate

$4.780 .44 \quad$ Most appropriate

$\begin{array}{lll}4.22 & 1.40 \quad \text { Very appropriate }\end{array}$

$4.78 \quad 0.44 \quad$ Most appropriate

$\begin{array}{lll}4.44 & 1.33 & \text { Very appropriate }\end{array}$

$4.50 \quad 0.80 \quad$ Most appropriate

Average

Note. Table 1 shows the result of the evaluation of input factors' readiness. The average results are as follows: the mean $(\bar{x})$ is valued at 4.50 . The standard deviation (S.D.) is equal to 0.80 . The quality level is rated as most appropriate.

Table 2. The Process of project-based learning using discussion and lesson-learned methods via social media

\begin{tabular}{|c|c|c|c|}
\hline Details & $\bar{x}$ & S.D & $\begin{array}{c}\text { The quality } \\
\text { level }\end{array}$ \\
\hline 1. Learning Preparation Stage & 4.78 & 0.44 & $\begin{array}{c}\text { Most } \\
\text { appropriate }\end{array}$ \\
\hline 2. Study a problem & 4.44 & 0.73 & $\begin{array}{c}\text { Very } \\
\text { appropriate }\end{array}$ \\
\hline 3. Specify a problem clearly & 4.67 & 0.71 & $\begin{array}{c}\text { Most } \\
\text { appropriate }\end{array}$ \\
\hline \multicolumn{4}{|c|}{ 4. Write a research proposal by making use of discussion via social media method } \\
\hline 4.1 Naming the project & 4.67 & 0.50 & $\begin{array}{c}\text { Most } \\
\text { appropriate }\end{array}$ \\
\hline 4.2 Proposing a person who will be in charge of the project & 4.56 & 0.53 & $\begin{array}{c}\text { Most } \\
\text { appropriate }\end{array}$ \\
\hline 4.3 Searching for an advisor for the project & 4.44 & 0.53 & $\begin{array}{c}\text { Very } \\
\text { appropriate }\end{array}$ \\
\hline 4.4 Identifying a source of project & 4.56 & 0.53 & $\begin{array}{c}\text { Most } \\
\text { appropriate }\end{array}$ \\
\hline 4.5 Identifying an objective & 4.56 & 0.53 & $\begin{array}{c}\text { Most } \\
\text { appropriate }\end{array}$ \\
\hline 4.6 Describing the project's methodology & 4.56 & 0.53 & $\begin{array}{c}\text { Most } \\
\text { appropriate }\end{array}$ \\
\hline
\end{tabular}


4.7 Setting up the budget

4.8 Benefits to be gained

5. Project Implementation

5.1 Find a target group

5.2 Discuss via social media for designing the details in each step of problem solving

5.3 Discuss via social media for designing an equipment to solve such problem

5.4 Operate the process of problem solving and record the past occurrence that was operated via social media

6. Discuss about the result of project operation and lesson-learned

7. Propose works of project and upload works via social media
4.22

0.83

$4.56 \quad 0.53$

Mos appropriate

Very appropriate

$4.67 \quad 0.50$

Most appropriate

$4.56 \quad 0.73$

Most appropriate

$4.44 \quad 0.73$

Very appropriate

Most

$4.67 \quad 0.50$ appropriate

$4.11 \quad 0.93$

Very appropriate

Very

$4.44 \quad 0.73$ appropriate

$4.52 \quad 0.62$
Most appropriate

Note. Table 2 shows the evaluated result of the process of project-based learning using discussion and lesson-learned methods via social media. The result's average values are as follows: the mean $(\bar{x})$ is valued at 4.52. The standard deviation (S.D.) is equal to 0.62 . The quality level is rated as most appropriate.

Table 3. Evaluation of the achievement in education and problem solving skills (output)

\begin{tabular}{|c|c|c|c|}
\hline Details & $\bar{x}$ & S.D & $\begin{array}{l}\text { The quality } \\
\text { level }\end{array}$ \\
\hline $\begin{array}{l}\text { 1. The achievement in education of undergraduate in education who learn with the } \\
\text { project-based learning using discussion and lesson-learned methods via social media }\end{array}$ & 4.56 & 0.73 & $\begin{array}{c}\text { Most } \\
\text { appropriate }\end{array}$ \\
\hline $\begin{array}{l}\text { 2. Problem solving skills of undergraduate in education who learn with the project-based } \\
\text { learning using discussion and lesson-learned methods via social media }\end{array}$ & 4.67 & 0.71 & $\begin{array}{l}\text { Most } \\
\text { appropriate }\end{array}$ \\
\hline Average & 4.62 & 0.72 & $\begin{array}{l}\text { Most } \\
\text { appropriate }\end{array}$ \\
\hline
\end{tabular}

Note. Table 3 shows the result of the evaluation of the achievement in education and problem solving skills (Output). The result's average values are as follows: the mean $(\bar{x})$ is valued at 4.62. The standard deviation (S.D.) is equal to 0.72 . The quality level is rated as most appropriate.

Table 4. Evaluation of the relationship between process and feedback

\begin{tabular}{lccc}
\hline Details & $\bar{x}$ & S.D & The quality level \\
\hline 1. Evaluate the readiness of the input factors & 4.67 & 0.50 & Most appropriate \\
2. Evaluate during the process of learning & 4.78 & 0.44 & Most appropriate \\
3. Feedback & 4.67 & 0.50 & Most appropriate \\
Average & 4.71 & 0.48 & Most appropriate
\end{tabular}

Note. Table 4 shows the result of the evaluation of the relationship between process and feedback. The result's average values are as follows: the mean $(\bar{x})$ is valued at 4.71 . The standard deviation (S.D.) is equal to 0.48 . The quality level is rated as most appropriate. 
Table 5. Overall evaluation of the developed learning model

\begin{tabular}{|c|c|c|c|}
\hline Details & $\bar{x}$ & S.D & $\begin{array}{c}\text { The quality } \\
\text { level }\end{array}$ \\
\hline 1. Analyze the readiness of the input factors & 4.56 & 0.53 & $\begin{array}{c}\text { Most } \\
\text { appropriate }\end{array}$ \\
\hline $\begin{array}{l}\text { 2. The process of Project-based learning using discussion and lesson-learned methods via } \\
\text { social media model }\end{array}$ & 4.44 & 1.01 & $\begin{array}{l}\text { Very } \\
\text { appropriate }\end{array}$ \\
\hline 3. Evaluate the achievement and problem solving skills (Output) & 4.56 & 0.73 & $\begin{array}{c}\text { Most } \\
\text { appropriate }\end{array}$ \\
\hline 4. Evaluate the result between process and feedback & 4.56 & 0.73 & $\begin{array}{c}\text { Most } \\
\text { appropriate }\end{array}$ \\
\hline Average & 4.53 & 0.75 & $\begin{array}{c}\text { Most } \\
\text { appropriate }\end{array}$ \\
\hline
\end{tabular}

Note. Table 5 shows the result of the overall evaluation of the developed learning model. The result's average values are as follows: the mean $(\bar{x})$ is valued at 4.53 . The standard deviation (S.D.) is equal to 0.75 . The quality level is rated as most appropriate.

\section{Conclusion}

- The PBL-DLL SoMe model has 4 components: 1) analysis of the readiness of the input factors 2) the process of project-based learning using discussion and lesson-learned methods via social media. 3) Evaluation of the achievement of learning and problem-solving skills (output) 4) evaluation of the result between evaluating and feedback as shown in Figure 1.

- In terms of the result of the evaluation of the developed project-based learning, the specialists have evaluated the appropriateness of the model and found that the mean $(\bar{x})$ of the PBL-DLL SoMe Model for enhancing problem solving skills of undergraduate in education student is valued at 4.53 . The standard deviation (S.D.) is equal to 0.75 . The quality level is rated as most appropriate.

\section{Discussion}

This research develops and evaluates the PBL-DLL SoMe Model for enhancing problem solving skills of undergraduate in education student based on the documentary research to be able to develop into learning model. The mean $(\bar{x})$ of overall evaluation of the developed learning model is valued at 4.53 . The standard deviation (S.D.) is equal to 0.75 . Therefore, the developed learning model is appropriate since the quality in overall is rated as most appropriate. To develop the PBL-DLL SoMe Model for enhancing problem solving skills of undergraduate in education student will use design instruction principle based on the concept of ADDIE Model and develop the learning model have steps as follows: 1) Analyze the readiness of the input factors. 2) The process of PBL-DLL SoMe Model. 3) Evaluate the achievement in education and problem solving skills (Output). And 4) evaluate the relationship between process and feedback that are consistent to the research of (Phromsila, 2011). According to the paper, managing the process of instruction by using ADDIE Model consists of 5 stages, including evaluating the needs and analyzing, designing, developing, testing, and evaluating the result for maintaining it based on the objective that has been set. According to this concept, there are also the evaluation and feedback between the processes as same as the developed learning method. The goal is to create the efficient learning and this is consistent to the research of (Krajcik et al., 2007) called "Learning-Goals-Driven Design Model: Developing Curriculum Materials That Align with National Standards and Incorporate Project-Based Pedagogy". The research result shows that learning model base on the research will support teachers in educating students by using the concept based on science and participation of learners and this is consistent to the research of (Wannapirun, 2011) called "The Research on the Development Integrating Learning Model by Using an Intellectual Equipment for Developing Critical Thinking" which is the research emphasizing components, process, and systematic procedure, and showing mutual relation based on the concept of ADDIE Model.

\section{Acknowledgments}

This work was supported in part by graduate studies, King Mongkut's University Technology North Bangkok, Thailand. 


\section{References}

Bell, S. (2010). Project-Based Learning for the 21st Century: Skills for the Future. The Clearing House (pp. 39-43). Taylor \& Francis Group. Routedge Taylor \& Francis Group: Newyork. http://dx.doi.org/10.1080/00098650903505415

Chainirand, P. (2012). Marketing via Social Media. Retrieved from http://cci.sru.ac.th

Kamemanee, T. (2004). Instruction Method by Using Group Work Discussion. Retrieved from $\mathrm{http}: / /$ thanaphon160333.wordpress.com.

Kannasud, P. (1999). Statistics for Behavioral Science Research (3rd ed.). Bangkok: Chulalongkorn University Press.

Krajcik, J., Mcneill, K., \& Reiser, B. (2007). Learning-Goals-Driven Design Model: Developing Curriculum Materials That Align with National Standards and Incorporate Project-Based Pedagogy. Retrieved from $\mathrm{http}: / / \mathrm{www}$.interscience.wiley.com

Office of the Education Council, Ministry of Education. (2007). The Guideline to Learning Management that Emphasizes on Learner 3. Learning Management by Using Problem as a Basis. Bangkok: Office of the Education Council.

Panmuk, L. (2009). The Guideline to Lesson-Learned/Project/Activity. Retrieved from http://www.banprak-nfe.com

Phromsila, B. (2011). The Development of E-book Interacting toward 10 Elements of National Health for 7th Graders. Innovative Education Research Online Journal, 1, 79.

Trakulsalid, W. (n.d.). Project-based Learning. Retrieved from http://www.kmutt.ac.th.

Wannapirun, P. (2011). The Development of Integrated Learning Model by Using Intellectual Equipment for Developing Critical Thinking. Research under the Faculty of Industrial Education, King Mongkut's University of Technology North Bangkok.

\section{Copyrights}

Copyright for this article is retained by the author(s), with first publication rights granted to the journal.

This is an open-access article distributed under the terms and conditions of the Creative Commons Attribution license (http://creativecommons.org/licenses/by/3.0/). 